\section{Accountability: An Overview of the Impact of Litigation on Professionals}

\section{H. Rutherford Turnbull, III}

It is now common to hear discussions about governmental accountability, its theorectical basis, the rights of consumers and clients in enforcing it, the strategies for securing it, and the consequences of abiding by it. In part, these discussions have been provoked by and are a response to frontier opening judicial acknowledgments of rights to education and treatment. They also are a response to court decisions (a) holding professionals personally liable in damages for treating patients in mental health and mental retardation institutions in professionally unacceptable ways or for refusing to treat them at all and (b) establishing and enforcing the right to treatment and education. To the extent that litigation has been the catalyst for imposing a principle of accountability to consumers and the public at large on professionals involved with the handicapped, it has been and will continue to be welcome, desirable, and even necessary.

\section{The Issues}

To know what accountability means is far from a difficult task. To make a person accountable is to challenge or contest him, or to hold him answerable; that which is accountable is capable of being explained; he who is accountable is held answerable.

To appreciate what accountability means, however, is a far more difficult task. Accountability raises a myriad of principal issues: Who holds whom responsible, for what action, according to what standards, under what theories of law, how, and for what reasons of rolicy. And there are a host of ancillary questions: What types of accountability ar $\varepsilon$ now required and are likely to be required in the future? What types of accountability should the law require? How far does or should accountability extend to a claimant of it? What interests in accountability are asserted by various claimants? How are the claimants' sometimes conflicting claims to be balanced against each other? Finally, how is accountability to be extended to various aspects of the client-provider relationship?

Viewed from the perspective of the law, none of these issues is free from immense complexity, although the answers to the principal issues seem simple. Who holds whom accountable? The client consumer holds the professional service provider accountable, responsible, and liable. For what action? For the manner in which the professional deals with, or fails to deal with, the client. According to what standards? According to standards developed in law for protecting the rights of other disabled persons, such as prisoners and minors, and also according to standards developed by professionals working with the handicapped. Under what theories of law? Primarily under the constitutional principles of due process and equal protection, as embodied in the 5th and 14th Amendments, and under a new application of the doctrine of cruel and unusual punishment under the 8th Amendment. How? By guaranteeing due process, by ordering remedies of violations of legal rights, and by requiring the professionals (and thus governments and the body politic) to treat disabled persons as equals and on equal terms. For what reason of policy? For the reason that, although humans are divisible into groups, human and constitutional rights are not.

\section{Underlying Principles}

Behind these complex judicial responses lie two major themes: First, human and constitutional rights are not divisible and may not legally be parcelled out according to the mental, emotional, or physical attributes of a person; and, second, the unequal person is entitled to equal treatment under the law.

Also behind these complex judicial responses lies the engrained belief of society, enforced at law, that persons should be answerable to each other for what they do to each other. In the law of trusts, the "prudent man" rule requires the caretaker of another's property to account to its owner for 
his actions. In the law of torts, the "reasonable man" rule requires that one person answer in damages to another for acting in an unreasonable way toward him and thereby injuring him. In the law of crimes, the right of the public to apply sanctions requires that persons who commit crimes against the public be punished, rehabilitated, and prevented from doing so again.

Although the concept of accountability is not new to the law, its present application to the providers of service to the handicapped is of recent origin, thus prompting the question, why? The reasons, of course, are manifold. Professionals recently have made such significant advances in understanding and treating disabled persons that they are thereby enabled and thus required to deal in new ways with respect to their clients. The public is newly aware of the needs of the disabled. Law reformers are engaged in the continuation of old civil rights battles on new battle grounds. Finally, this is an age of egalitarianism, an age that is capable of adopting as its tenets the indivisibility of human and constitutional rights and the essential equality of all persons.

\section{The Right to Treatment}

The court decisions establishing the right to treatment have two principal goals-the improvement of the condition of the handicapped person himself, and the improvement of the conditions in which the person is treated or confined. The unstated predicate of these decisions is that an improvement in the person will result from an improvement in his environment. The unstated implication is that neither type of improvement can occur unless professionals can be held to account for at least the environmental conditions and their professional relationships to their clients.

\section{Three Legal Theories}

To hold the professionals accountable, the courts have resorted to three well known legal theories. The first is procedural due process, which guarantees a person the right and a meaningful opportunity to protest and to be heard before government may take action with respect to him. This is the rule that the government must proceed fairly before it acts (usually applied to commitment of the mentally ill or retarded). Second is substantive due process, which signifies that there are certain rights and privileges that a state may not arbitrarily take from a citizen (such as the deprivation of liberty through confinement) and that the state may not act unreasonably, arbitrarily, or capriciously in dealing with a citizen. Third is equal protection, which guarantees to the handicapped person the same rights and benefits all other citizens have with respect to their government (including all of the constitutional rights of procedural and substantive due process) unless the withholding of the rights or benefits by the state is for a valid reason that justifies the state in singling out the handicapped person for differential treatment.

These theories are applied solely by reason of the fact that the handicapped person is confined by the state and is in its custody. It is the creative application of these theories that is the vehicle for insuring the state's and professionals' accountability.

Procedural due process, for example, has been applied to prevent unjustified civil commitments to mental institutions (Baxstrom $v$. Herald, 1966; Specht v. Robinson, 1967; McNeil v. Director, Patient Institution, 1972). It is also beginning to be applied to prevent unjustified transfers from one type of an institution to another (Kessalbrenner $v$. Anonymous, 1973). Both applications advance the principle of accountability - that professionals be required to justify the action they propose to take before being allowed to take it.

Substantive due process, for example, has been applied to civil confinement, the nature and duration of which bears no reasonable relation to the purposes for which the person was confined (Jackson v. Indiana, 1972; Wyatt v. Stickney, 1971). If the purpose of confinement is habilitation or treatment, confinement may not partake of merely custodial care or, worse, punishment. Substantive due process thus advances accountability by requiring the state and its professionals to provide habilitation and treatment.

Finally, equal protection requires that a person's civil confinement be justified by a rational reason or compelling state interest (since confinement affects the fundamental right of personal liberty). This requirement can be satisfied only if treatment and rehabilitation are furnished, since the person is 
classified as needing confinement on the basis of his need for treatment. In the absence of confinement with treatment, there is no rationality or compelling state interest in the classification or confinement, and the person's equal protection guarantee is violated (Baxstrom v. Herald, 1966). In the same manner as substantive due process, equal protection advances a principle of accountability.

\section{Other Judicial Responses}

The exact nature of the state's duty to treat those it has confined has not been agreed upon, and it is misleading to suggest that judicial responses to claimed accountability are unanimous. Indeed, some courts have rejected the federal constitutional basis for the duty (Burham v. Georgia, 1972), while others have held that the state's duty is only to prevent deterioration or harm (NYARC v. Rockefeller, 1973). Some, however, have held that the state's duty is to habilitate (Wyatt v. Stickney, 1972; Welsch $v$. Likens, 1974), and those courts have had no problem in devising the standards of that obligation and the methods for overseeing its implementation.

\section{The Standards}

The new standards for insuring accountability are those recently created by the mental health and mental retardation professionals themselves. They are the standards of the Joint Council on Accreditation of Hospitals, American Association on Mental Deficiency, Accreditation Council for Facilities for the Mentally Retarded, and Department of Health, Education, and Welfare (Rockefeller, 1973; Wyatt, 1972; and Donaldson v. O'Connor, 1974).

The courts have been reluctant to impose all of the professionally created standards at one time and have instead required compliance with minimum standards (Wyatt, 1972; Rockefeller, 1973; Welsch, 1974; and Donaldson, 1974), for the stated reason that the state had insufficient fiscal ability to implement all of the professional standards at one time (Rockefeller, 1973; Wyatt, 1972). In what ways are minimum standards applied? They are applied principally by requirements that staff personnel be increased in quantity and upgraded in quality (Wyatt, 1972; Welsch, 1974), and by prohibitions or restrictions on certain types of treatment (Welsch, 1974;
Rockefeller, 1973; Wyatt, 1972). Curiously, the Welsch court recently found that the 8th Amendment's prohibition of cruel and unusual punishment had been violated by forms of seclusion, physical restraint, and chemotherapy, as practiced. Previous courts had found violations of 5th and 14th Amendment due process or equal protection but not of the 8th Amendment. Standards have also been applied by the requirement (Wyatt, 1972; Welsch, 1974) that individualized treatment plans be developed for the residents of state institutions. These requirements have serious implications for educators of the handicapped, as discussed later.

The courts may also have hesitated to require full and immediate compliance with the new standards for other reasons (e.g., a belief that such a requirement would be mocked because of the obvious impossibility of compliance, a sense that their decisions will be acceptable only if they can be complied with). They may also have realized that a substantial restructuring of the institutional care system would be required and that they are not in a good position to monitor the details of the change or to oversee the implementation of massive court ordered change. Nevertheless, by requiring minimum standards of treatment to be furnished, the courts have moved out boldly to assure accountability. Whether their actions will prove to have unwanted or unexpected consequences is a different matter.

In the right to treatment litigation, the courts are assuring accountability by applying principles emanating from a constitution that itself derives from the people as their statement of limitations on the power of government and of the duties of the government to them. Other governmental responses to the needs for accountability having been inadequate (i.e., legislative and executive avenues), the courts have been the only remaining governmental source for requiring accountability. Although they have taken this role by default, in the end this may prove to be the most successful way to insure public and professional accountability. Surely the courts can do no worse than a self serving bureaucracy or an inattentive legislature.

\section{The Right to Education}

A nationwide attack is under way against public school practices that deny equal edu- 
cational opportunities to handicapped persons.

These practices include totally excluding handicapped persons from the public school (PARC v. Commonwealth, 1972; Mills v. D.C., 1972; MARC v. Maryland, 1974), unjustifiably classifying persons as retarded (Larry P. v. Riles, 1972; LeBanks v. Spears, 1973; Diana v. State Board of Education, 1973; Guadalupe Org. v. Tempe, 1972), funding special education as special services at lower levels than regular education services (Mills, 1972; MARC, 1974), establishing separate criteria for admission of handicapped persons to the school systems (PARC, 1972; Mills, 1972), limiting the size of special education classes and the capacity of special educational programs (David P. v. State Dept. of Education, 1973), and failing to provide education to home bound or institutionalized persons (MARC, 1974). Collectively, these practices demonstrate the lack of accountability by the state to the handicapped where accountability means fulfilling a duty to educate both the handicapped and the normal pupil.

\section{Defined by the Courts}

The court-ordered remedies address each of the discriminatory practices, thus attempting to assure accountability. Statutes and practices that permit exclusion have been held unconstitutional (PARC, 1972; Mills, 1972; MARC, 1974). Zero reject policies have been established (PARC, 1972; Mills, 1972; MARC, 1974). The implementation of mandatory education for the handicapped legislation has been judicially supervised (Rainey v. Watkins, 1973; Panitch v. Wisconsin, 1972; contra, Harrison v. Michigan, 1972). Compensatory educational opportunities for the handicapped have been ordered (Mills, 1972; LeBanks, 1973). Alternatives to in classroom education have been decreed (MARC, 1974). School budgets have been ordered to be increased or amended to provide for education for the handicapped (Mills, 1972; MARC, 1974). Classification criteria have been ordered to be revised (LeBanks, 1972). IQ tests have been temporarily suspended (Larry P. v. Riles, 1972). Finally, procedural due process has been imposed on school exclusion and classification decisions (PARC, 1972; Mills, 1972).

In the right to education litigation, then, accountability means adhering to compulsory school attendance laws, extinguishing exclusionary and unjustifiable classification practices, affirming the principle that all persons are capable of learning and developing (PARC, 1972; Mills, 1972; MARC, 1974). It also means affirming the opportunity of the handicapped to receive appropriate education (Lau v. Nichols, 1974; Guadalupe v. Tempe, 1972; Serna v. Portales, 1972), and affirming the responsibility of the state to deal fairly (through procedural due process) with the handicapped. Additionally, erasing and compensating for long standing deprivations and discrimination, providing a free education, furnishing an education to all handicapped persons, whether they are in their communities or in state institutions (MARC, 1974), and redefining the traditional 3 R's concept of education (MARC, 1974) all come under the definition of accountability.

\section{The Right to Access}

The increasing willingness of courts to permit consumers to have access to educational records concerning them also serves to advance the principle of accountability. Access is granted under the safeguards of procedural due process (PARC, 1972; Mills, 1972; LeBanks, 1973) as well as under federal statutes (P.L. 93-380, Sec. 513) and state statutes (e.g., General Assembly of North Carolina, Ch. 1293, 1973 S.L., 2nd Sess.) for reasons of accountability.

It is appropriate for educators to collect information so that they can better know what a pupil's needs are and can make better judgments about what is in his best interest. However, the pupil also has an interest in the information and is entitled to access to it to insure that it is correct and that decisions based on it are justified by it. Without access he is unable to hold the professional accountable, and professional efforts at denying access may often be correctly seen as resistance to accountability.

In light of such resistance it may be salutory to provide a statutory remedy that grants not merely the right of access, copying, clarification, and expunction but also grounds for the civil action of mandamus (court ordered access) and a misdemeanor level criminal sanction. By the same token, the disclosure of information, without the justification of 
necessity for treatment or placement decisions, for example, likewise is hard to tolerate on grounds of acceptable professional conduct. A technique for assuring professionalism and accountability for unjustified disclosure has been a lawsuit for invasion of privacy, breach of contract, breach of fiduciary relationship, or defamation. However, since damages are usually difficult to prove in such cases and since the legal elements of any of these actions are sometimes hard to satisfy, a misdemeanor level crime might be a more effective technique.

\section{The Rights of the Individual}

Accountability as imposed by the courts in right to education litigation minimally means requiring the state to do what it has undertaken to do-provide an appropriate education to all pupils, including the handicapped. It means more than this, however. The requirements that procedural due process must be satisfied before placement and classification decisions are made tend to focus attention on the individual student's needs, rights, and interests. As the requirement that individualized treatment plans be developed for the institutionalized person brings the person, not his environment, to stage center, so too the procedural due process guarantee forces educators to do what they have been reluctant or unable to do before - to individualize education. Moreover, the $P A R C$ and Mills requirements of appropriate educational placement likewise carry the implication of individualized education. It hardly overstates the case to assert that right to education litigation will revolutionize the educational practice of treating students as members of a group or as components in an aggregated consumer group.

\section{The Goal}

There is a unifying theme to these judicial efforts. The new theme is that education must be child centered rather than system centered. To assert this is one thing; to insure it is altogether another. School systems are intractable. There is no consensus on what is the proper or sound educational practice to be followed in the case of handicapped persons, and the bureaucratic structure of the schools tends to thwart the child centered changes that the courts require. Moreover, change by the judicial route is particularly incremental, usually taking up one case at a time and, even in the class action litigation, being without power to insure the effective and meaningful implementation of judicial decrees. What educators, legislatures, and consumers have been unable to do over many years-insure equal educational opportunity to the disabled and individualize educationone cannot expect the courts to accomplish overnight. Accountability in the sense of equal educational opportunities for all exceptional children is still a distant goal.

\section{Personal Liability}

In the right to treatment and right to education litigation, courts have attempted to insure accountability by imposing rules of conduct on whole institutions (for the mentally ill and mentally retarded) and systems (of public education). Their efforts are directed at assuring accountability on a grand scale; they attempt to make the professionals in the institutions or systems accountable by requiring that the institutions and systems themselves become accountable. Yet there is a great difference between court orders directed at institutions and systems, on the one hand, and orders directed at individuals themselves, on the other. The former rarely carry personal liability (except sometimes for contempt of court for noncompliance or dismissal from employment for noncompliance or incompetence), while the latter always do (by personal liability for damages).

\section{Two Examples}

Two prominent illustrations serve to emphasize the accountability mileage that can be gained through actions for personal liability. Doctors at a state institution for the mentally ill have been held personally liable to a patient for their bad faith refusal and inexcusable failure to provide him with even the most minimal and rudimentary psychiatric treatment (Donaldson v. O'Connor, 1974). In addition, personal damages have been sought against a doctor who performed and state officials who authorized an unnecessary or unjustified involuntary sterilization (Cox v. Stanton, 1974). Accountability can often be most expeditiously accomplished through the pocketbook device of personal liability. Indeed, personal liability may effect more system changes than all the minimum standards' requirements of a host of cases. It has the 
power to personalize the obligation of accountability in a far more direct, understandable, and significant way than the more usual litigation against institutions and systems. It carries power over money.

\section{Other Appropriate Applications}

To date, physicians have been the most likely persons against whom the principle of accountability has been applied, through money damages for bad faith, malpractice and deprivation of constitutional rights of liberty and treatment (Donaldson v. O'Connor, 1974). Yet there is no reason to think that the same principle should not be asserted against other professionals. Thus, bad faith action that fails to comply with generally recognized standards of acceptable professional conduct may become actionable in cases involving educators (e.g., for unjustified classification), nonmedical administrators of institutions (e.g., for illegal confinement), and psychologists (e.g., for deprivation of certain basic needs, such as clothing, food, or bedding, as part of behavior shaping token economies). Surely the standards of competence and accountability that the law applies to the medical profession will be appropriately applied to other professions as well, especially where the medical professionals frequently jointly participate with other professionals in making interdisciplinary judgments concerning such important matters as confinement, treatment, habilitation, and educational placement and classification. These professionals should be held accountable in personal liability for their bad faith failure to give advice or engage in conduct that measures up to and is consistent with the generally recognized standards of acceptable conduct in their respective professions.

It may be the task of the courts to set those standards in advancing the interests of accountability. Surely consumers will not ignore the effect that such standard setting may have in improving the quality of the services they receive.

To the end that the principle of accountability is made applicable to the many affected professions, the state's shield of sovereign immunity and the provision of statutory exculpability or immunity for professionals should be seriously reconsidered. If the shield protects the individual whose bad faith ac- tions fail to measure up to the standards of appropriate professional conduct, it serves only the questionable state purpose of protecting those who should not be protected. That surely is not a legitimate use of the shield. Moreover, it thwarts the consumer interests of accountability. The interests of immunity and exculpability on the one hand, and accountability on the other, can best be served by immunity or exculpability from good faith actions only.

\section{Conclusion}

The courts predictably will be asked to handle many more cases directed at professional accountability and the subject matter of those cases will become increasingly diverse and complex. For professionals who have acted as though they are above rules of accountability, this prospect must be alarming and disarming. For those who have traditionally recognized that they are subject to the rules of accountability, the prospect may be managerially annoying, but not much worse. For all persons the prospect should be welcomed, for it ultimately will result in improving the social conditions of the handicapped. If their social conditions are improved, one may hope that their capacities likewise will be improved.

\section{References}

Baxstrom v. Herald, 383 U.S. 107 (1966).

Burham v. Georgia, 349 F. Supp. 1335 (N.D.Ga. 1972) app. filed No. $72-3110$ (5th Cir. Oct. 5, 1972).

Cox v. Stanton, Cir. Act. No. 800 (U.S.D.C., E.D.N.C., filed July 12, 1973) app. filed (by plaintiff upon grant of defendants' motion for dismissal of proceedings upon pleadings on grounds of statute of limitations) (4th Cir., filed Sept. 23, 1974).

David P. v. State Dept. of Education, Cir. Act. No. 658826 (S.F. Super Ct., filed April 9, 1973).

Diana v. St. Board of Education, C-70-37 R.F.P. (N.D. Cal. Jan. 7, 1970 and June 18, 1973).

Donaldson v. O'Connor, 493 F.2d 507 (5th Cir. 1974).

Guadalupe Org. v. Tempe Elementary School Dist. No. 3, Cir. Act. No. 71-435 (D. Ariz. 1972).

Harrison v. Michigan, 350 F. Supp. 846 (E.D. Mich. 1972).

Jackson v. Indiana, 406 U.S. 715 (1972).

Kesselbrenner $v$. Anonymous, 33 N.Y.2d 161, 305 N.E.2d 903,350 N.Y.S. 889 (1973).

Larry P. v. Riles, 343 F. Supp. 1306 (N.D. Cal. 1972).

Lau v. Nichols, 94 S.Ct. 786 (1974), dicta on appropriateness of education.

LeBanks v. Spears, 60 F.R.D. 135 (E.D. La. 1973).

Maryland Association for Retarded Children (MARC) v. Maryland, Cir. Ct., Baltimore County, Equity No. 100/182/77676 (May 3, 1974).

McNeil v. Director, Patuxent Institution, 407 U.S. 245 (1972). 
Mills v. Board of Education of District of Columbia, 348 F. Supp. 866, 968, 875 (D.D.C. 1972).

NYARC v. Rockefeller, 357 F. Supp. 752, 755-6, 758, 768 (E.D.N.Y. 1973).

Panitch v.State of Wisconsin, No. 72-C-461 (E.D. Wisc., filed Aug. 14, 1972).

Pennsylvania Association for Retarded Citizens (PARC) v. Commonwealth, 334 F. Supp. 1257 (E.D.Pa. 1971) and 343 F. Supp. 279, 282, 296 (E.D.Pa. 1972).

Rainey v. Watkins, Civil No. 77620-2 (Chancery Ct. Shelby County, Tenn., filed April 5, 1973).

Serna v. Portales, 351 F. Supp. 1279 (D.N.Mex. 1972). Sprecht v. Patterson, 386 U.S. 605 (1967).

Welsch v. Likens, 373 F. Supp. 487, 495-497-9 (D.Minn. 1974), and subsequent order of October 1, 1974 (43 L.W. 2151).

Wyatt v. Stickney, 325 F. Supp. 781, 784 (M.D.Ala. 1971).

Wyatt v. Stickney, 344 F. Supp. 387, 391, 395-407 (M.D.Ala. 1972), aff'd. sub. nom. Wyatt v. Anderholt (43 L.W. 2208, 5th Cir. Nov. 8, 1974).

H. Rutherford Turnbull, III is Associate Professor of Public Law and Government, Institute of Government, the University of North Carolina at Chapel Hill. This article is from an address to the Great Lakes Region annual meeting, American Association on Mental Deficiency, Fort Wayne, Indiana, October 3, 1974.

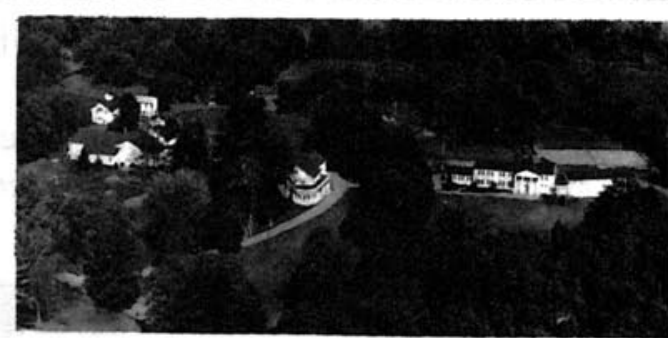

\section{MAPLEBROOK SCHOOL}

Amenia, New York 12501

Mrs. John Finger, Dean of Students

Since 1945 outstanding residential, co-educational school for students 11 through 18 with I.Q. 75 or higher with diagnosed learning disabilities derived from minimal brain damage, perceptual impairments, and secondary emotional symptoms.

Successes are achieved through a humanistic, non-therapeutic approach emphasizing peer group relationships.

Ungraded curriculum through 8th grade. Sports, horseback riding, handicrafts, art, music, field trips, summer camp. Additional programs to prepare for after graduation and first opportunity in vocational training program at Chapel Haven, New Haven, Conn. for Maplebrook graduates.

Chartered by N.Y. State Dept. Education, approval various state aids, Champus, and non-discriminatory for qualified students.

Write Maplebrook School, Amenia, N.Y. 12501 Mrs. M. Finger, Dean (914) 373-8191.

\section{Living Therapy...}

for mentally retarded children of all ages.... any intellectual level

With five separate campusesall psychiatrically orientedBrown Schools has a geographic separation necessary for the proper residential milieu, yet has the benefits from the combined talents of our staff.

Two of our campuses are primarily for the mentally retarded and/or those with learning disabilities. We seek to provide self-help with academic and social training to the maximum degree of the student's ability.
Available are prevocational training and supportive therapy, together with help for daily living for those who require it. Different only in the types of students who are enrolled and in the level of training provided, our campuses together form a

program for the mentally retarded of any age, sex or level of retardation.

Write: The Director of Admissions / Department D1 / THE BROWN SCHOOLS / P.O. BOX 4008, Austin, Texas 78765. Toll Call: (512) 478-6662 Out of State Toll Free: (800) 531-5305 From Texas Free: (800) 292-5404

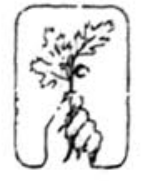

The Brown Schools

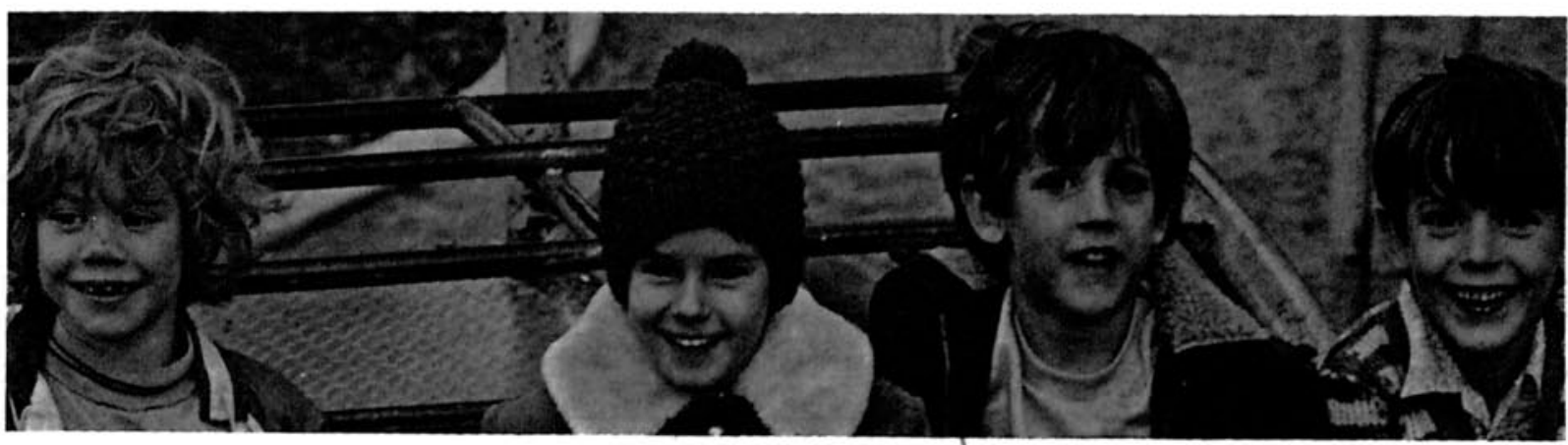

